\title{
In defense of conviviality and the collective subject
}

\author{
Manuel Callahan \\ Universidad de la Tierra Califas, San Diego, USA. Email: motin-dr@riseup.net
}

\begin{abstract}
This essay takes up the question of a "new" social paradigm by first examining the recent emergence of the U.S. Occupied Movement (OM) as a provocative and inspiring moment of political re-composition, but one that also narrates a more complex unraveling of what W.E.B Du Bois called "democratic despotism.” The most recent political tensions and economic "crisis" of the global north point to the disruption of a white "middle class" hegemony alongside inspiring moments of reconstructed conviviality. I suggest that the tension within spaces of occupation and convergence are animated by conviviality that should be read "politically" by noting the emergence of tools in service of community regeneration. Towards that end, I introduce Universidad de la Tierra Califas, a local project somewhere in-between network and collective pedagogies that is also a project of strategic conviviality and a Zapatismo beyond Chiapas. I argue that UT Califas engages a collective subject as part of an epistemological struggle inspired by Indigenous autonomy currently underway throughout Latin America.
\end{abstract}

Key words: autonomy, collective subject, conviviality, democratic despotism, necropolitics, insurgent learning.

\section{En defensa de la convivialidad y del sujeto colectivo}

Resumen: En este ensayo se aborda la cuestión de un «nuevo» paradigma social, examinando en primer lugar la reciente aparición del estadounidense Movimiento Ocupado (OM) como un momento provocador e inspirador de recomposición política, pero que también narra un desenlace más complejo de lo que W.E.B. Du Bois llama «despotismo democrático». Las tensiones políticas más recientes y la «crisis» económica mundial del extremo norte señalan la interrupción de la hegemonía de la «clase media blanca” junto a momentos de inspiración de convivencia reconstruida. Se sugiere que la tensión dentro de los espacios de ocupación y convergencia, están animados por la convivencia que puede ser leída «políticamente» al apreciar la aparición de herramientas al servicio de la regeneración de la comunidad. Con ese fin, se presenta la Universidad de la Tierra Califas, un proyecto local en algún punto entre la red y las pedagogías colectivas, que también es un proyecto de convivencia estratégica y un zapatismo más allá de Chiapas. Se sostiene que UT Califas se acopla a un sujeto colectivo, como parte de una lucha epistemológica, inspirado por la autonomía indígena actualmente en curso en América Latina.

Palabras clave: autonomía, sujeto colectivo, convivencia, despotismo democrático, necropolítica, aprendizaje insurgente.

\section{Em defesa da convivência e do sujeito coletivo}

Resumo: Este ensaio tem-se a questão de um «novo» paradigma social, analisando o recente surgimento do Movimento EUA Ocupados (OM) como um 
momento provocador e inspirador da política de recomposição, mas que também narra um desenlace mais complexo do que W.E.B. Du Bois chamou de «despotismo democrático.» As mais recentes tensões políticas e «crise» econômica do norte global mostra o rompimento da hegemonia de um branco «classe média» ao lado de momentos de inspiração de convívio reconstruído. Eu sugiro que a tensão dentro de espaços de ocupação e convergência são animados por convívio que deve ser lido "politicamente», observando o surgimento de ferramentas no serviço de regeneração da comunidade. Para este fim, apresento Universidad de la Tierra Califas um projeto local em algum lugar entre a rede e pedagogias coletivo que é também um projeto de convívio estratégico e um zapatismo além Chiapas. Defendo que UT Califas envolve um sujeito coletivo, como parte de uma luta epistemológica inspirado na autonomia indígena em curso na América Latina.

Palavras-chave: autonomia, sujeito coletivo, convívio, despotismo democrático, necropolitics, aprendizagem insurgente.

The question of a new social paradigm is critical. ${ }^{1}$ For some, it is already here. For others, we are at an undeniable threshold. But, what actually constitutes this new social paradigm and how to advance it remains a topic of some debate. Much of the discussion centers around a number of initial questions, including some disagreement if we are yet able to fully observe it, and, if so, where do we observe it most clearly? How is this new paradigm advanced? Can the praxis associated with it be reproduced in other sites? I agree with others that a new social paradigm is certainly underway. More importantly, it is most easily observed in the "dislocated spaces, [where] rhythms are disrupted and the social roles imposed by the dynamics of domination are forgotten.” (Ceceña, 2012: 113) This “new” social paradigm is most easily observed in the multiple spaces of convivial reconstruction underway, including, but not limited to the space of Indigenous autonomy throughout Latin America. ${ }^{2}$

In what follows I want to offer three areas for reflection and these in relation to the question of a new social paradigm. The first revolves around the need to be clear about how we are analyzing the current conjuncture. I suggest we advance the discussion of a "new social paradigm" by first recognizing the need to agree somewhat on how we are reading the current conjuncture in relation to "crisis." I stress the importance of reflecting on the current moment to propose that how we read the "crisis" determines in large part what we are able to observe regarding the dynamics, opportunities, and challenges of different spaces of opposition. Highlighting our approach to analysis draws our attention to the complexities of the current conjuncture while also exposing the epistemological dimensions of the many trajectories of struggle that animate this moment. I insist that the current moment presents not only a particular set of “crises," but a epistemological struggle. ${ }^{3}$ The recent emergence of the U.S. Occupied Movement (OM), for example, punctuates a provocative and inspiring moment of political re-composition, but it also narrates a more complex unraveling of what W.E.B Du Bois called "democratic despotism." More than simply a disruption of financial 
markets or the political instability that results from austerity programs, the current political tensions that reverberate through the wave of occupations, emerging commons, and community assemblies point to the disruption of a white "middle class" hegemony alongside inspiring moments of reconstructed conviviality. "The individualism which was imposed on the colonies, today nation-states,” explains Jaime Martínez Luna, “is reaching its limit in regard to the development of equality and democracy as it confronts the truly vibrant epistemological proposal of comunalidad." (Martínez Luna, 2012: 85)

Second, given that many spaces have become infused with or potentially animated by a conviviality, I want to briefly interrogate Ivan Illich's monopoly of the concept by "reading him politically" much in the same way Harry Cleaver suggests for reading Marx, namely to engage him strategically. A political reading takes as its perspective the working class and "self consciously and unilaterally structures its approach to determine the meaning and relevance of every concept to the immediate development of working class struggle.” (Cleaver, 2001: 30) Toward that end, I briefly consider conviviality as a "methodology," or tool, for analysis and imagine it as a strategy in relation to an emerging “collective subject.” My primary point of reference for both conviviality and a collective subject is the EZLN and the diverse Zapatista solidarity community that has emerged with them. In addition, I am also informed by local efforts to pursue a Zapatismo beyond Chiapas. Unfortunately, space does not permit a thorough discussion of the contributions the Zapatistas have made to strategic discussions about how we might promote a collective subject as an emerging force of democratic renewal. ${ }^{4}$

Third, I want to briefly examine local efforts that attempt a strategic conviviality that I also read as an attempt at a Zapatismo beyond Chiapas. In this case, I examine the Universidad de la Tierra Califas, a project currently underway in the southern portion of the San Francisco Bay Area and Southern California. I read its engagement with conviviality through insurgent learning and convivial research, an autonomous political praxis that embraces a collective subject and insists that knowledge production is a fundamental dimension of popular democratic processes and pre-figurative politics. At the core of UT Califas' convivial reconstruction is an effort to make learning an on-going dimension of democratic renewal. Insurgent learning is a "new form of learning: a kind of learning nourished by the experiences and sensitivity of old fighters and by new ideas that desecrate the sanctuaries of power." (Сeceña, 2012: 113)

\section{The “Crisis" of Democratic Despotism}

San Jose, like much of the country, has been infected by a rash of occupations and assemblies. Unfortunately, there has been little to distinguish Occupied San Jose (OSJ), from much of the OM. Indeed, OSJ, to most observers, has been overshadowed by the more militant and creative 
mobilizations underway in San Francisco and Oakland. ${ }^{5}$ San Jose has not earned any special attention in the politics of occupation. However, while San Jose is only one of many occupations most observers associate with the Arab Spring and indignados of Spain, it does provide some critical insight into how we currently define and analyze "crisis."

What converted a rather lack luster occupation in San Jose from a predictable, scripted protest to a display of democratic despotism's unraveling begins with a simple gesture to share new facilitation tools and techniques with OSJ's General Assembly (GA). Responding to a pattern of marginalization in the GA, a number of representatives from San Jose's ethnic Mexican community advocated for a more inclusive and diverse assembly process. Towards that end, representatives of San Jose's diverse ethnic Mexican community agreed to facilitate a GA and introduced an approach borrowed from the asamblea popular most prominently on display during the Oaxaca commune. ${ }^{6}$ After presenting a somewhat modified facilitation strategy intended to address issues specific to the dynamics of OSJ, the guest facilitation team initiated the day's proceedings. ${ }^{7}$ The facilitators for the day opened the GA by inviting local Native American elders to inaugurate the gathering with a brief ceremony to acknowledge prior claims to the land being used for the GA, celebrate ancestors, and honor the present gathering.

In short order, many of the most prominent and active members of the GA, as it was then constituted, voiced their outrage. A number of the OSJ's recognized "leaders" denounced the proceedings, shouting that they did not want a "Hispanic revolution." The most vocal declared that Movimiento Estudiantil Chican@ de Aztlán (M.E.Ch.A.) and a network of Spanish-speaking separatist groups were hijacking the GA. After hours of accusations, righteous indignation, and unsolicited paternalism the GA was reclaimed by "the majority” of active GA participants (read white), especially those keen on making sure working committees could fulfill their charge and resume the bureaucratic chores of presenting committee report backs. The gesture was an effort to reclaim the "real business" of the GA and the OSJ. Unfortunately, the tension at the GA proved that many of "the occupiers" might be able to protest banks, direct invective at ineffective elected leaders, and reclaim abandoned public squares, but that Sunday they demonstrated they cannot or are unwilling to learn complex strategies of assembly and community formation increasingly associated with a new politics of encounter from the ethnic Mexican community of Greater Mexico. ${ }^{8}$

The unfolding of the OM in San Jose is a stark contrast from the political energies that converge in other parts of the San Francisco Bay Area, especially the North and East Bay. To be sure, the experience in San Jose reveals a dimension of the social and racial antagonism observed in portions of other occupations associated with the OM. However, I evoke San Jose's experience with the OM to suggest that what is at stake in the current conjuncture is not only a moment of capitalist crisis but also to 
underscore the limits of democratic despotism. The political tensions exposed in OSJ echo the political restrictions witnessed in, for example, Arizona and increasingly other states as political forces continue to mobilize and invest in strategies of "differential inclusion" and preemptive prosecution primarily directed at the Mexican community. ${ }^{9}$ Moreover, the expulsion of the region's ethnic Mexican community witnessed at OSJ reenacts the rigid racial barriers that inform much of the OM's mobilization as well as the larger society.

One of the principal achievements of the OM has been to introduce a shared language of opposition against capitalism and the elites who profit most by it. The success of the OM according to George Caffentzis was "the remarkable job of attracting many new strata of the 99\% (or what used to be the working class) to the occupy site.” Besides bringing more of what was "traditionally" known as the working class back into the political process, OM facilitated a shift away from representative political strategies to a "body politics," or the necessity "to have to bodily be at the center of the circulation of cities to practice politics.” Additionally, many have been inspired, come to learn, or been reminded of the power of the street. More people have taken to the street Caffentzis notes to convert public space into community commons even at times using the antiquated tactic of the siege. Most importantly, the OM has proven to be a "self-reproducing" movement in the sense that it puts reproduction at the center of political work, reducing the gap between the "personal and the political.” (Caffentzis, 2012) Along with the infectious energy of reclaiming commons there is a growing awareness about the importance of linking work, environmental, health, food, and safety at the level of community struggles. Thus, the OM has successfully brought a number of critical issues to the attention of the mainstream and has begun to shift the "common sense" beyond the reliance on political machines and the non-profit industrial complex. Notable among these are the criminal transfer of wealth by elites; excessive force deployed by militarized police; systemic restrictions to commons; and the limits of a representative system of governance that pretend at democracy.

Unfortunately, even a cursory review of the achievements of the OM cannot escape the difficulties around race especially notable in multiple efforts to decolonize occupied spaces. Declarations of "we are the $99 \%$ have been challenged by groups who believe they have been excluded or marginalized from occupy spaces. Much of the discussion has been focused on the complications of inclusion. Not surprisingly, "decolonizing" the space in many instances has been limited to issues of representation, mirroring in many ways how racial violence is diffused through identity politics. Declarations that the $\mathrm{OM}$ has been the first or is unique in articulating struggles for rights, equity, and access have been met with the subtle and at times not so subtle reminder that historically marginalized groups have been fighting for their homes, wages, and healthcare for some time.

Less than a month after the incidents in San Jose, observers were shocked at police violence directed at occupiers peacefully assembled at 
UC Davis. In this context OM also exposed what Dylan Rodriguez calls the "political abyss" of U.S. liberal-progressive politics. In the context of occupied, police violence has been increasingly directed at emboldened occupiers even finding its way to the occupations on University campuses. Police excess at UC Berkeley, and later UC Davis, for example, outraged many sympathetic to the OM and further raised the awareness of even those only recently aware of the struggle. Escalation of police misconduct occurred when riot-clad UC Davis police brutally pepper sprayed campus occupiers. Police brutality directed at mostly students generated an immediate and vocal disapproval, including from folks only moderately interested in the OM. The police debacle at Occupy Davis underscored how militarized policing that has been a central part of a larger strategy of low intensity war directed at historically marginalized communities and youth of color for the last thirty years can be, according to Rodríguez, increasingly applied to all variety of protestors. Rodriguez reads the chasm as one "that allows for acute indignation to be reserved for the policing of those presumed racially innocent (white)" against the violence inflicted on criminalized Black and Brown bodies who are daily victims of "undisguised modalities of domestic racialized warfare.” Rodríguez rightfully concludes that racial antagonism still "structures major strains of many progressive, social justice oriented struggles, including the domestic Occupy Movement.” (Rodríguez, 2012: 301-313)

Thus, the OM embodies the uneasy tension between militant intervention and convivial reconstruction within a context of persistent racial inequality. External limits are the organized police attacks under the pretext of enforcing “municipal biopolitical ordinances.” (Caffentzis, 2012) The repression is a coordinated effort of multiple law enforcement agencies at the local, state, and federal level. Internal limits include the discord in the encampments. For some the encampments are an expression of the "spontaneity" that Ceceña refers to in relation to subaltern resistance. Spontaneity embodies "a long ruminated freedom" and "learning through invention.” (Ceceña, 2012: 114) Others, many new to active public political involvements, worry about "sending the right message" and mobilizing greater participation or sympathy by not appearing excessive or extreme in the deployment of specific tactics and the development of a long-term strategy. The recent accusations against the Black Bloc as a disruptive force within Occupied Oakland, for example, underscore the political struggles between those who insist on an "organized" PR campaign competing to "get the right message out" and those who occupy as a strategy intent on liberating spaces, reclaiming commons, and deploying a "diversity of tactics." One faction is being careful to stay within the parameters of dominant discourses that authorize political activity while the other struggles to imagine a space beyond capital and the state.

Although confronted by external and internal limits, the OM still is able to facilitate politically potent moments of conviviality. Thus, the OM is at a critical turning point. How to disrupt dominant forces and still maintain convivial reconstruction? At stake is the challenge of moving beyond the 
initial "spontaneity" to constructing a space for co-generation of intercultural knowledges and strategies capable of embracing or inventing alternatives to capital and the state.

The violent and coordinated dislocation of the OM from public space underscores how occupation has refocused attention on "democracy" as a renewed site of struggle. The spectacles of "oligarchic democracies" that manage interests through "free" elections, political parties, corporate press, and financial markets proceeds against the back drop of the OM's internal and external struggle -those who insist on converting occupation into an organization within the existing framework of a representative bureaucracy confront refuseniks who prefer to embrace it as a process and strategy. According to Kristin Ross, democracy either describes the undeniable capacity of people to manage their own lives or "a world government centered on great wealth and the worship of wealth, but capable of building consensus and legitimacy through elections that, by limiting the range of options, effectively protect the ascendency of the middle and upper classes." (Ross, 2011: 98) "What we've witnessed in the countries we call 'the democracies,"” adds Jacques Rancière, "has been a mistrustful and faintly or openly derisive attitude toward democracy.” More to the point, "a large part of the dominant discourse is working in one way or another against democracy.” (Rancière, 2011: 76) But, it is democracy that is a vital site for radical transformations - "a method of doing the impossible." "It is," explains W.E.B Du Bois, "the only method yet discovered of making education and development of all men a matter of all men's desperate desire." (Du Bois, 1915: 712)

It is worth repeating that the provocations, challenges, and opportunities of the OM emerge within a context of extreme levels of persistent, everyday violence organized through the intersections of permanent global war, militarization of the everyday, and the increasing privatization of violence articulated in part in the virulent forms of differential inclusion and abandonment. ${ }^{10}$ Since 9-11, the Patriot Act, and, more recently, the approval of the National Defense Authorization Act underscore the perceived threat to political liberty racialized enemies pose, underscoring that "freedom" at home depends on "democratic empire" and the U.S.'s efforts to advance democracy abroad. According to Sylvia Federici: "it is in the irreducible nature of the present capitalist crisis that no mediation, either at the level of programs or institutions are possible, and that development planning in the Third World gives way to war." (Federici, 2000: 153)

The battle over "democracy" as a consensus building process that celebrates faith in the capacity of people to manage their own lives rather than submit to a failed representative system takes place alongside a spectacle of violent racial restriction directed against the ethnic Mexican community of Greater Mexico. The recent killing of two migrants by an armed group of camouflaged vigilantes just outside of Eloy, Arizona underscores a permanent war at home executed by just about any fanatic with a gun eager 
to «patrol the border.» All too common violent assaults, custodial misconduct, and police and border patrol shooting deaths operate alongside a growing apparatus of preemptive prosecution exemplified in Alabama's HB 56 and Arizona's SB 1070. Attacks and exclusions have reached a level dangerously in sync with political processes more common to fascism when books are banned and ideas made illegal as in the well-funded and orchestrated campaign against Mexican American Studies in Tucson. Targeted use of I-9 raids directed at selected factories across the country spreads terror to key portions of the ethnic Mexican workforce. Increased deportations alongside the expansion of detention centers have become one of the main growth areas of the Prison Industrial Complex and insure its longevity. Despite local law enforcements disfavor and, in many notable cases resistance, to S-Comm, a nation-wide dragnet continues to terrorize whole communities with a devastating impact on families that are increasingly torn apart due to alarming rates of deportations. The severe criminalization of undocumented status promised in HR 4437 and S 2611 that earlier had mobilized over two million protesters in 2006 has become de facto if not de jure. The current battle underway in places like Arizona reminds us that even exercising the most benign democratic principles can pose a serious threat, leading to increased levels of criminalization of "historically underrepresented" communities, securitization of already failed schools in low income areas, and privatization of all areas of redress organized through the non-profit industrial complex.

\section{The Unraveling of Democratic Despotism}

The current opening created by the wave of occupations has not only revealed the disruption of international capitalism as much as a breakdown of "democratic despotism." The confrontation with "the American paradox" is best observed by the sustained rebellion against structural adjustments, followed by the serial protests of the alterglobalization movement, and, more recently, the wave of occupations sweeping the globe. These occupations have finally reached the U.S. after more than thirty years of pitched battles and autonomous alternatives that have confronted Structural Adjustment, Free Trade, Privatizations, and Low Intensity Conflict coordinated in the intersecting wars against drugs, migrants, terror, and the social factory. More importantly, this critical moment of political re-composition has also witnessed the fraying edges of what once was a "democratic nation composed of united capital and labor." (Du Bois, 1915: 709)

In the U.S. "crisis” has been used somewhat successfully to organize racialized violence directed at various "enemies of the state" at times decomposing the class and always deflecting attention away from the state apparatus. ${ }^{11}$ The manufacture and manipulation of "crisis" makes possible the production of an ideological surplus value that organizes relations within a system of globalized white supremacy. Ruth Wilson Gilmore argues that from "the genocidal wars against Native Americans to the totalitarian chattel 
slavery perpetrated on Africans, to colonial expansion, to the obliteration of radical anti-racist and anti-capitalist movements, the annals of US history document a normatively aggressive, crisis-driven state.” From slavery through colonial expansion, including domestic disruption of oppositional movements, "the US has been committed to the relentless identification, coercive control, and violent elimination of foreign and domestic enemies." The state claims "permanent ideological surplus value in the realm of 'defense'” on a number of scales. Gilmore's theorization of ideological surplus value links strategies of representation to the material and structural violences of capitalist command and primitive accumulation organized through racial and gender hierarchies. Moreover, Gilmore's analytical framework exposes hegemonic apparatuses that at their core depend on power relations organized through a permanent war that articulates the state's "capacity to wield despotic power over certain segments of society." (Gilmore, 1998/99: 178) "Racism," she concludes, "is a practice of abstraction, a death dealing displacement of difference into hierarchies that organize relations within and between the planet's sovereign political territories.” (Gilmore, 2002: 21) By insisting on the fundamental intersection between the production of surplus value and ideological surplus value more generally, Gilmore complicates our notion of a politics of representation by not only interrogating how we live or experience race in relation to hegemonic apparatuses but also underscores how knowledge production is integral to capitalist command.

W.E.B Du Bois has also examined the production of ideological surplus value in his investigation of global war and the intersection of racial difference, nation building, representative democracy, and colonial occupation. Du Bois' opposition to WWI pointed to the competition between ambitious, predatory colonial states and the need for capital to placate a white working class elite as the cause of war and all future wars. According to Du Bois, the U.S. industrial working class enjoys material and psychological benefits as a labor aristocracy -a position only made possible through the brutal exploitation of workers in the colonies. In practical terms, the white working class welcomed concessions from capital in the form of modest control over working conditions, higher wages for a few luxury goods, and, most importantly, the "psychological wage" of a perceived superiority over another worker. ${ }^{12}$ More importantly, white working class privileges are consolidated through a system of representative democracy, an accompanying nationalist identity, and the select opportunities of citizenship. ${ }^{13}$ White working class composition requires the production and maintenance of internal and external colonies through an expanding system of persistent wars. Thus, the "imagined communities" of capitalism are necessarily produced through organized violence as much as a dependence on print culture. ${ }^{14}$

Thus, for Du Bois the political crisis embodied in World War I, indeed all wars on a global scale that would follow, have at their root the competition for the plunder of Africa -a continent considered, then as now, as having little to do with the world affairs of Europe and the U.S. Acknowledging a 
long history of African civilization, Du Bois recounts that "lying treaties, rivers of rum, murder, assassination, mutilation, rape, and torture have marked the progress of Englishman, Frenchman, German, and Belgian on the dark continent." The investment in Africa responds to the political imperatives of "economic changes in Europe" as much as from the temptation for lucre.

Slowly the divine right of the few to determine economic income and distribute the goods and services of the world have been questioned and curtailed. We called the process Revolution in the eighteenth century, advancing Democracy in the nineteenth century, and Socialization of Wealth in the twentieth. But whatever we call it, the movement is the same: the dipping of more and grimier hands into the wealth bag of the nation until today only the ultra-stubborn fail to see that democracy in determining income is the next inevitable step to Democracy in political power.

The world, Du Bois concludes, invested in "color prejudice" and established a color as Europe was "groping towards a new imperialism." Thus, the American Paradox spreads across the globe. "It is this paradox," Du Bois explains, "which allows in America the most rapid advance of democracy to go hand in hand in its very centers with increased aristocracy and hatred toward darker races.” (Du Bois, 1915: 709)

Du Bois astute linking of nationalism and state building with the psychological benefits of membership in an "imagined community" articulated through race and dependent on the continued exploitation of workers in the "developing world," invites a more sophisticated approach to war. Interrogating the privileges of a psychological wage, Du Bois draws attention to the thin ideological veneer that makes it possible to celebrate some wars, especially those that narrate the heroic rise of the nation-state, and justify others as necessary. War is a permanent affair always present if organized on different, some time smaller scales and far away locations. (cf. Retort, 2005) But, more importantly, the national bond sharpened through imperial competition is only possible through war's domestication. At the center of this more complex process of domestication is the successful erasure of colonial violence.

Democratic despotism is not possible without, as Achille Mbembe has astutely argued, the world's first "state of exception" in the form of slavery and colonial occupation. Mbembe's recent interrogation of "state of exception," biopower, and the multitude echoes an earlier critique proffered by Du Bois and Aimee Cesaire. ${ }^{15}$ Many postcolonial intellectuals have taken prominent European theorists to task for assuming that the violent history of European fascism in the mid-twentieth century is somehow singular. At the root of Mbembe's more recent intervention is a concern that critics of late modernity have too quickly accepted fascism and the concentration camp as the unique embodiments of violence specific to Europe of the twentieth century. ${ }^{16}$ Underlying the telos of European fascism is a brutal history of "discovery" and a discursive apparatus that masks 
earlier moments of equally brutal "exception,” namely slavery and colonial occupation. Mbembe's introduction of colonial occupation as a category re-centers the debate and recovers a much longer history of extreme, dehumanizing violence that long precedes European fascism's arrival. Occurring through successive periods of modernity, there can be little doubt that contemporary forms of expansionist and international warfare are the by-products of an on-going European, capitalist colonialism. ${ }^{17}$ These new forms of exceptional violence continue the mechanisms articulated through colonial occupation.

According to Mbembe, colonial occupation has always been "a matter of seizing, delimiting, and asserting control over a physical geographical area -of writing on the ground a new set of social and spatial relations." These new spatial relations produced "boundaries and hierarchies, zones and enclaves; the classification of people according to different categories; resource extraction; and finally, the manufacturing of a large reservoir of cultural imaginaries.” Moreover, it is the imaginaries generated through colonial violence that "gave meaning to the enactment of differentiated rights to differing categories of people for different purposes within the space; in brief the exercise of sovereignty. Space was therefore the raw material of sovereignty and the violence it carried with it. Sovereignty meant occupation, and occupation meant relegating the colonized into a third zone between subjecthood and objecthood.” (Mbembe, 2003: 25-27) Of course the production of boundaries and the discursive systems they reinforce not only work through the colony but include "the frontier" and "the border." 18

The colony "as a formation of terror," according to Mbembe, is made possible through Europe's domestication of war. The success of a European juridical order, or jus publicum Europaeum, through the two key principles of the juridical equality of all states and the territorialization of the sovereign state, determine specific boundaries within a global order and make it possible for certain privileged states to enjoy "the right to wage war." "Under jus publicum," explains Mbembe, "a legitimate war is, to a large extent, a war conducted by one state against another or, more precisely, a war between 'civilized' states." "The centrality of the state in the calculus of war," Mbembe adds, "derives from the fact that the state is the model of political unity, a principle of rational organization, the embodiment of the idea of the universal, and a moral sign.” The effort to " "civilize' the ways of killing” attributing rational objectives to extermination also worked in conjunction with the determination of "those parts of the globe available for colonial appropriation.” (Mbembe, 2003: 24) Thus, the colony, according to Mbembe, is the site "where sovereignty consists fundamentally in the exercise of a power outside the law (ab legibus solutus) and where 'peace' is more likely to take on the face of a 'war without end."”

Europe's success in domesticating war makes it possible for the colony to work as a "formation of terror." The colony operates as "the zone where the violence of the state of exception is deemed to operate in the service of 'civilization.'” Consequently, colonies, much like the frontier, 
can only be "inhabited by savages" and subsequently denied "a state form." Thus, they do not imply "the mobilization of sovereign subjects" and therefore cannot claim distinct armies and legal recognition as enemy combatants in a context of a formal war conducted with agreed upon protocols and concluded with a ritualized peace. That is they are outside of the social apparatus of warfare that define the international system of sovereign states. The violence essential to colonial subjugation can never be elevated to the status of "just war" or the warfare between sovereign states. (Mbembe, 2003: 23-25)

Mbembe historicizes colonial occupation into three periods culminating in late modern colonial occupation that combines disciplinary, biopolitical, and necropolitical formations. The necropolitical, or "contemporary forms of subjugation of life to the power of death," organizes weapons "deployed in the interest of maximum destruction of persons and the creation of death-worlds." In this instance, a new biopolitical formation determines vast populations are "subjected to conditions of life conferring upon them the status of living dead." Palestine represents "the most accomplished form of necropower.” It marks a shift from early modern to late modern colonial occupation where more contemporary forms of warfare converge in the colonial state's ability to "derive its fundamental claim of sovereignty and legitimacy from the authority of its own particular narrative of history and identity.” (Mbembe, 2003: 39-40; 25-27) Thus, Gaza and the West Bank, for example, embody both the excesses of contemporary wars and the logics of colonial occupation. ${ }^{19}$

As the brutality of WWI raged on Du Bois asked, "what are we to do, who desire peace and the civilization of all men?” After noting wryly that peace-niks mostly confine themselves to war's costs and "platitudes on humanity," he reminds us that nations care little about spending millions in materiel or losing an equal number of lives when war insures greater access to spoils. Du Bois insists that those of us who want peace "must remove the real causes of war" by extending "the democratic ideal" to all peoples. "We shall not drive war from this world until we treat them as free and equal citizens in a world-democracy of all races and nations." (Du Bois, 1915: 712)

\section{Convivial Reconstruction and the Collective Subject}

I have titled this essay, “In Defense of Conviviality,” not so much to suggest that conviviality needs any special advocacy, but rather to highlight that it remains a grossly overlooked and, as a consequence, under theorized concept. ${ }^{20}$ In one sense, conviviality needs little to no explanation or further theorization given that it is a fundamental dimension of humanity. We are by definition biologically and socially convivial even if that conviviality is not always so visible due to the mediation of other forces. Therefore, I propose we think about conviviality in at least two ways -one treats conviviality as fundamental to human kind and present as part of a sacred 
process of social renewal and the other approaches it as an effort to reclaim those social processes in specific political contexts. Thus, the struggles to engage conviviality can be observed in oppositional spaces over time and in specific instances. The necessity to reclaim conviviality as a category of analysis, political objective, and political praxis is underscored by the lessons gleaned from the many political successes of what Zibechi calls "societies in movement.” (Zibechi, 2010; Zibechi, 2012)

The relation between a conviviality that is both a sacred process and a historical praxis echoes the tension between the political and politics. Sandro Mezzadra reminds us that the debate between what constitutes the political and politics has been central to movement discussions since '68. More importantly, it has inspired efforts "exploring and materially building a political landscape beyond the state." 21 The significance of an imaginary beyond the state cannot be over emphasized. It is in the political, as the space for radical imaginaries to flourish, that a politics beyond the state must take root. And, it is in the space of the political that conviviality is always present. It is, as Ceceña reminds us, in the play of subjectivities where difference is nurtured in spaces of rebellion. ${ }^{22}$ Its conviviality's essential characteristics, as part of the political, that makes it vital to politics and, not surprisingly, why it is in that realm it is most often restricted. Nowhere has that denial been more evident than in the political marginalization of indigenous autonomous projects emerging from the Global South. Conviviality has had a special resonance in indigenous autonomous movements that resist colonization, internal colonialism, and neocolonizations ${ }^{23}$ The struggle over conviviality throughout the Americas continues to challenge, inspire, and facilitate anti-colonial, anti-capitalist, and anti-state struggles.

Thus, reclaiming Illich politically requires approaching conviviality as a strategic category. It is worth noting that Illich did not use conviviality as an ontological category as much as a category to highlight the strategies that precede and resist the imposition of industrial tools. At the center of conviviality is an effort to restore our capacity to manage our lives in harmony with our tools. Illich approaches tools "broadly" in order "to subsume into one category all rationally designed devices, be they artifacts or rules, codes or operators, and to distinguish all these planned and engineered instrumentalities from other things such as basic food or implements, which in a given culture are not deemed to be subject to rationalization." Consequently, tools can range from "simple hardware" to "productive institutions" or "productive systems" as well as "intangible commodities" associated with health, education, etc. The importance of tools cannot be overestimated given that they "are intrinsic to social relationships.” They are so fundamental to society that "an individual relates himself in action to his society through the use of tools that he actively masters, or by which he is passively acted upon." (Illich, 1990: 21-22)

Illich defines convivial tools as "those which give each person who uses them the greatest opportunity to enrich the environment with his or her 
vision." As a consequence, convivial tools promote "individual freedom realized in personal interdependence.” Tools advance conviviality when they are easily accessible and in service of the user. Convivial tools, therefore, do not imply "the total absence of manipulative institutions and addictive goods and services." Rather, a convivial society manages "the balance between those tools which create the specific demands they are specialized to satisfy and those complementary, enabling tools which foster selfrealization." (Illich, 1990: 24) Thus, a convivial society emerges through "social arrangements that guarantee for each member the most ample and free access to the tools of the community and limit this freedom in favor of another member's equal freedom.” A society that maintains a balance allows, "all its members the most autonomous action by means of tools least controlled by others.” (Illich, 1990: 20)

Illich made every effort to insure that conviviality would not be treated as an abstract category. He worried that if he were only to "deal with political strategies and tactics" it would divert attention away from his main argument. However, I propose Illich made it possible to engage conviviality as a strategic concept. By strategic I mean thinking in action in relation to the actual "reconstruction of convivial tools." In order to advance conviviality as a strategic category, or to read Illich politically, I suggest in Illich can be found a "methodology." First, we must distinguish industrial from convivial tools. Second, Illich's method makes it possible to determine the kinds of industrial devices that impact our lives and when they have exceeded their limits. Industrial tools that no longer are in service of their users must be recognized for their corrosive impact on social processes. In other words, we must determine the manner that they undermine dignity and restrict the lives of their users rather than being in the user's service. Thus, Illich proposes convivial reconstruction begin with an examination to determine at what point tools have begun to exceed their purpose and are no longer serving everyone without limiting an other's desires and restricting their relationship to the local environment. The goal is to work toward "society of responsibly limited tools." An advanced "methodology" further distinguishes between corrosive and collective tools by distinguishing between different kinds of institutional arrangements: "there are tools which can be used normally for fully satisfying, imaginative, and independent work; others tend to be used primarily in activities best labeled as labor; and finally certain machines can only be operated." Of course, only the former is convivial. Illich calls for an additional strategic effort in order to analyze imperialism according to "the pernicious spread of one nation beyond its boundaries; the omnipresent influence of multinational corporations; and the mushrooming of professional monopolies over production.” Thus, there can be little doubt that the state is a primary tool within the industrial mode of production.

Illich's collective research at CIDOC advanced an awareness that "a society committed to high levels of shared learning and critical personal intercourse must set pedagogical limits on industrial growth.” (Illich, 1990: $\mathrm{x})$ In short, the project of discarding corrosive or limited tools and the effort 
to construct new convivial tools must take up issues of deprofessionalization, cultural regeneration, political balance, and ecological harmony of a community of struggle. Illich frequently points to velocity as a way of reading the excess in the industrial mode of production. "Speed is one of the means by which an efficiency-oriented society is stratified.” (Illich, 1990: 38) Discussion about the velocity of politics has been central to Zapatismo's commitment to engage political work "at the pace of the slowest."

The wave of occupations and assemblies sweeping the U.S. extend some of the more militant strategies and practices increasingly common to the Global South. The current excitement has reawakened interest in the political possibilities of a collective subject. Unfortunately, the Left has not been a faithful companion to the collective subject. Although the Left originates from a critical analysis of inequality, it has not consistently put forward a praxis that privileges analysis of a collective subject as the critical agent of social change. The Left has been most promiscuous, for example, in those instances that it has allowed individualism, elitism, and vanguardism to determine its political practice and organization. More often than not, the Left has taken the collective subject for granted, assuming it alone has unquestioned rights and access to it politically and socially.

In its arrogance, the Left has overlooked the opposition's seduction of a neglected companion. Of course, in the company of the political mainstream the collective subject has been capable of all kinds of mischief and in many instances the most obscene kinds of violent excess -the lynch mob, the corporation, and the nation-state come readily to mind. ${ }^{24}$ But, here too, the Left has been opportunistic. Too often the Left has allowed its own opposition to be organized around the manipulations orchestrated by elites and vanguards as in the trust it has often placed in bureaucracies and the political party. In its zeal, the Left has been all too comfortable with formations more common to political and social conservatism such as in the case of the cult and apparatuses peculiar to the state. Neglectful, the Left has under theorized the collective subject even though it has been faithfully by its side for some time.

The collective subject poses a number of problems and opportunities for a politics of emancipation. First, as I suggest above, the collective subject has not entirely been exclusive to emancipatory or oppositional projects. "The modern state," Gustavo Esteva warns us, "is the ideal collective capitalist.” (Esteva, 2009: 46) Second, in a manner similar to conviviality, there is the preeminent danger of treating the collective subject only as an abstract category rather than a concrete social body of real people situated in a specific context and organized for a particular purpose. ${ }^{25}$ The collective subject I have in mind is not static, one-dimensional, nor homogenous, but rather a composition of diverse subjects that respond to the challenges at hand without being over determined by any overarching, disciplining discourse. Third, a collective subject is by definition a convivial subject and, therefore, requires a rebel pedagogy. Collective subjects are not hatched or produced fully formed. Rather, a collective subject acts on a shared desire. 
Fourth, in order for a collective subject to exist as a convivial subject it must be democratic. A collective subject that is able to "balance ends with means" does so through locally rooted horizontal spaces of dialogue that can manage difference through a collectively determined set of intercultural processes. This process requires tools. Although some groups are believed to have a special connection or insight to convivial processes while others are dismissed as having been to submissive to industrial tools, we must accept that all people are fundamentally and at all times capable of engaging or reconstructing conviviality.

A collective subject emerges through the active claims of "dignity." (Holloway, 1998: 159-198) It is when assertions of dignity are unmediated by, for example, industrial tools that it can be the driving force of a conviviality -a space where all dignities flourish. When we approach dignity as a strategic category of struggle that also implies a political objective and a political praxis, we affirm that the space of dignity is a space of learning. Thus, we must learn how to celebrate the dignity of others and to construct spaces for that mutual recognition to flourish. A collective subject that embodies an unmediated conviviality is by definition in balance with its tools. Collectively invented tools for the purpose of community regeneration must be invented, tested, and agreed upon in order to successfully address local issues and access locally rooted wisdoms. ${ }^{26}$ A critical dimension of an emerging collective subject forged in convivial reconstruction is epistemological. Convivial tools are produced through a shared process of (re)discovery, agreement, and regeneration.

The proliferation of “convergence spaces” (and projects) within the alter-globalization movement and advances in digital technologies has made subaltern knowledge production more widely known and increasingly accessible. More importantly, it has demonstrated the growing importance of knowledge production for social justice projects and spaces. The intersection between tactical advances in social movements and the creative re-appropriation associated with insurgent cultural spaces has placed knowledge production at the forefront of community regeneration. Illich's notion of conviviality can assist in exposing how insurgent learning flourishes in the "dislocated" spaces and "spontaneous" moments of an emerging struggle in opposition to capitalist and state apparatuses that have reached their limits as overwrought industrial tools.

\section{Insurgent Learning and Collective Pedagogies}

I want to continue my examination of the intersection of conviviality with a collective subject by briefly introducing an insurgent learning space currently underway in Northern and Southern California, namely the Universidad de la Tierra Califas. ${ }^{27}$ My motivation in presenting Uni-Tierra Califas is twofold. I want to avoid the trap of putting forward abstract categories by grounding my earlier discussion of conviviality and a collective subject in an autonomous praxis I hope can be easily observed in Uni-Tie- 
rra Califas as a space of encounter that serves as a strategy, political objective, and a political space. Additionally, I explore both the possibilities and obligations that accrue to conviviality as a strategic effort.

Before taking up Uni-Tierra Califas it is worth interrogating collective pedagogies that re-center local practices of knowledge production away from institutions that privatize and monopolize knowledge practices. Mainstream institutional sites most often fail as vibrant sites of learning. "Education” is, as Illich warned, the paradigmatic industrial tool. There are at least two ways of approaching pedagogies that insist "education" can take place outside of the formal school system and beyond the university. The two approaches of collective pedagogy I mention here are an example of "networked pedagogies" and those processes of collective learning based in comunalidad. The first disrupts the dominance of institutional, formal sites of privatized knowledge while the second fully decolonizes education.

Transductores, an excellent example of a successful networked pedagogy reclaims the task of education by recognizing the interconnectedness of multiple agents, alternative media, and variety of institutions. Transductores decentralizes knowledge production by connecting a variety of agents, projects, and sites as well as links cultural processes with pedagogical ones. Refusing to limit learning to single “pedagogical events" typical of transmission strategies, network pedagogy celebrates learning in "the spaces of social networks, where individuals interact, desire, and configure ourselves every day.” Thus, according to Javier Rodrigo Montero, a collective pedagogy is necessarily unpredictable, unstable, and irregular. (Montero, 2009: 242)

Comunalidad, a somewhat different approach to collective pedagogy, shifts the focus from education as the domain to prepare individuals within the discursive formations of progress and development to an emphasis on community regeneration that stresses the value of reciprocity and rootedness. A collective pedagogy that results from a more complex process of community renewal claims a variety of cultural and social resources committed to community renewal. Comunalidad, according to Luna, is "the epistemological notion that sustains an ancestral, yet still new and unique, civilizing process, one which holds back the drecipit individualization of knowledge, power, and culture.” Although it emerges out of a historical context of resistance to colonialism, internal colonialism, and neocolonialism, comunalidad, as Martínez explains, is a pedagogy that promotes harmony between individuals and the community and the community with the environment. ${ }^{28}$ "Comunalidad is a way of understanding life as being permeated with spirituality, symbolism, and a greater integration with nature. It is one way of understanding that human beings are not the center, but simply a part of this great natural world.” (Martínez Luna, 2012: 86; 93-94) Thus, comunalidad creates a context for knowledge sharing that is integral and dialogic. (Ferrer, 2003: 29-32)

Taking seriously Jorge Gonzalez’s admonishment that "the way we 
organize ourselves to produce knowledge will determine the knowledge we produce," we recognize the challenge in pursuing a collective pedagogy that anticipates the relation between strategies of knowledge production and social relations, underscoring that a collective pedagogy is always contingent and emergent. (González, 2003) If we only focus our efforts on disrupting formal education as an industrial tool we lose sight of other knowledge practices and spaces of learning that could potentially undermine and eventually go beyond the authority of the subject/object relationship, the celebration of the individual, and imposition of capitalist labor discipline. More importantly, in a social setting dominated by industrial tools, convivial knowledge practices in service of community regeneration must be, in many instances, re-learned in order to be reclaimed.

UT Califas is not modeled after nor does it attempt to replicate or compete in any way with a traditional institutional educational environments organized around the classroom, seminar, lecture hall, or institutional archive. UT Califas subverts transmission pedagogies typical of traditional teaching and research institutions by refusing to organize organizers, teach teachers, or train trainers who bestow knowledge to "the community."

Universidad de la Tierra Califas works as a collective pedagogy in a number of interconnected ways. As an unfinished effort, it has been imagined in relation to other emergent projects and situated sites of autonomous learning. It attempts to braid together a number of interconnected spaces of co-learning and skill sharing as part of a larger effort to "re-weave the social fabric” of a community. As a relation, UT Califas celebrates knowledge production animated by the itineraries of deprofessionalized intellectuals, community-based researchers, and insurgent learners. UT Califas incorporates established movement and capacity building projects, popular education spaces, and participatory action research efforts in order to recirculate the grassroots "technologies" and situated knowledges that address immediate, local struggles. Committed to social difference, political justice, and economic equity, UT Califas converts diversity trainings into dialogues, employment hierarchies into shared, collective work projects, and service learning into networked community spaces that collectively address local struggles related to California’s changing demographic.

UT Califas poses as a set of questions, how do we learn from the projects mostly associated with "dislocated spaces” and autonomous projects including and most especially those "societies in movement" associated with indigenous autonomy. UT Califas is a cautious effort to engage the convivial praxis of the Indigenous Autonomous movement especially its articulation at the Universidad de la Tierra “campuses” in Oaxaca, Chiapas, and, most recently, Puebla. UT Califas is committed to learning about how learning works especially drawing wisdom from communities of struggle organized around community regeneration, reciprocity, and balance. However, the effort implies a commitment to explore the challenges and opportunities that emanate from intercultural dialogues that are tenuous and not easily undertaken, especially in a context of a "democratic 
despotism" not yet fully dismantled. Our hope is to pursue a collective pedagogy in urban, landless contexts with few cultural resources but that can still cultivate a studied reciprocity and sacred connection to place. Thus, UT Califas in the South Bay imagines a decentralized and diffused horizontal learning project as a cargo, or collectively entrusted obligation for community renewal that pursues research and learning projects organized as community determined tequios de investigación. The goal of a combined insurgent learning and convivial research approach is to engage the epistemicide common to Western notions of progress, development, and civilization. (de Sousa Santos, 2008)

UT Califas is not confined to any buildings nor does a cumbersome bureaucracy constrict it. Its "architecture” does not occupy a physical space or shelter a bureaucratic structure. Rather, it should be understood much in the same way as the Aymara have deployed the "barracks" in their struggle for local autonomy which, according to Zibechi, "are social relationships: organizational forms based on collective decision-making and the obligatory rotation of duty, but in a militarized state or, in other words, adapted to cope with violent assault.” (Zibechi, 2010: 53-55) The proposed architecture includes a Center for Appropriat(ed) Technologies, ${ }^{29}$ Language and Literacy Institute, ${ }^{30}$ Theses Clinic, ${ }^{31}$ Study Travel Jornadas, ${ }^{32}$ and a Democracy Ateneo. ${ }^{33}$ Each pillar only functions as long as insurgent learners and convivial researchers claim specific spaces. By insurgent learning we refer to a praxis that imagines the sharing of knowledge as a critical element of radical democratic practice. On a practical level, insurgent learning undermines low intensity education through explicit, horizontal practices that reclaim the everyday spaces of learning. It also introduces complex process of communal regeneration. Most importantly, it mobilizes learning as an essential part of an on-going effort to insure that the entire community is sufficiently informed and prepared to engage community decision-making.

"Pedagogy" in service of communal processes can be observed in the Zapatistas' political project. The Zapatistas have been successful making insurgent learning and convivial research a fundamental part of a "new way of doing politics." Throughout their public presence they have consistently reiterated their commitment to learning and research as part of their effort to remain informed and engage alternatives. Their emphasis on knowledge production has been especially apparent in their military preparation, encounter with civil society, and exploration of autonomy. Learning runs throughout the two periods of Zapatismo: Fire and the Word. In the first period, the preparations for war were marked by analysis of the militarypolitical situation; use of arms, managing security; military drill and formation; and mastery of the Spanish language. During the strategic encounter with civil society in the second period, the Zapatistas discovered as much about new ways of presenting themselves as they learned about civil society's struggle against neoliberalism. A unique process of co-learning unfolded through the variety of encounters, mobilizations, and consultations that the Zapatistas strategically convened as a part of their research about neoliberalism, the political class' crises, and the success of civil society's 
prior efforts of opposition. No doubt, the EZLN and the complex solidarity community they activated shared a great deal together in the space of encounter created by the series of encuentros, consultas, and marchas. A shared commitment to a new way of doing politics requires learning a new way to learn.

The current phase of Zapatismo is noteworthy for the Zapatistas' commitment to a politics of autonomy. The Zapatistas have engaged autonomy by working through the practice and sharing the theory afterwards. Zapatista commitment to learning has meant that they have established a context for knowledge to be affirmed and shared as they manage strategies to make available new and reclaimed knowledges in the areas of land, health, education, and governance. The Zapatistas' introduction of the caracole and juntas de buen gobierno, for example, not only construct a space of encounter, but also makes possible a civic pedagogy. The caracoles authorizes "minor" or situated knowledges while the JBGs enable community members to participate politically, making it possible for everyone to master the arts of governance. (Gonza'lez Casanova, 2005)

Publically negotiating the tension between elite and subjugated knowledge production, the Zapatistas have played a much more complicated role than simply inspiring serial protests, cleverly managing their media image, or astutely making use of the internet. The Zapatistas' politics of encounter, a consistent strategy of facilitating broad, inclusive political spaces for dialogue without directing the outcomes encourage active participation that facilitates the emergence of a self-active, autonomous collective subject.

The most observable effort to combine a network pedagogy with an investment in comunalidad as part of a larger attempt at a Zapatismo beyond Chiapas is UT Califas' Temporary Autonomous Zones of Knowledge Production (TAZKP). In an effort to transcend the limits of bureaucratic structures, institutional sites, and professional identities, UT Califas' strategically engages interconnected, diffused, and decolonized spaces. As everyday spaces of collective pedagogy, TAZKP refuse to impose a preordained or established structure for learning. ${ }^{34}$ TAZKP are open spaces that extend "the classroom" and celebrate collective strategies of knowledge production and invite insurgent learners to engage multiple sites of locally generated knowledges as part of an effort to regenerate community.

TAZKP reclaim public spaces as sites of situated and poetic knowledges in service of community regeneration taking advantage of how knowledge overflows formal and informal sites and projects. TAZKP can be very deliberate, strategically networked sites or simply spontaneous spaces. Once reclaimed, TAZKP regenerate a social infrastructure of community. As on-going spaces of encounter for research, reflection, and action, TAZKP make possible a variety of political and intellectual itineraries by facilitating the convergence of different groups, projects, and networks. (Rodrigo Montero, 2009: 242) In short, the TAZKP is and encourages 
“relays.” (Deleuze and Guattari, 2005; Foucault, 1977)

TAZKP politicizes "traditional" cultural practices and spaces by converting them into active deliberate spaces of knowledge production. In the case of UT Califas four cultural practices, including tertulia, ateneo, mitote, and coyuntura have been reclaimed/reinvented as part of a larger autonomous praxis. Although each reclaimed cultural practice is subject to shifting meanings given the variety of class, gender, and race tensions peculiar to specific gatherings as well as the contexts in which each is convened, together these cultural practices function as an open space of encounter organized for the purpose of grassroots knowledge production appropriate for the specific context or network of projects and spaces that it articulates. In keeping with a convivial itinerary, each cultural practice reclaims and politicizes the code that narrates it by redeploying it for political uses. The most public and less formal, the tertulia politicizes regular local gatherings often common to barrios as sites to generate and archive local histories of struggle. ${ }^{35}$ Often criminalized in the popular consciousness, the mitote works as a reclaimed public space of celebration convened to generate poetic knowledges that privilege arts, dance, and embodied research. ${ }^{36}$ We deploy the ateneo not as a space typical of the academy such as an advanced seminar, conference, workshop, plenary, or research cluster but to insist on it as an open, diffuse space that can facilitate locally generated investigations. ${ }^{37}$ As a space that allows us to gather as a diverse situated community, it potentially transcends bureaucratic structures and professional identities to promote reflection and action. The coyuntura draws from the popular education practices inspired by the work of Paulo Friere and Ivan Illich, encouraging participants to generate new tools for analysis as they collectively engage a series of activities organized around reflection and action. ${ }^{38}$ As spaces that reclaim commons, regenerate community, and facilitate intercultural and intergenerational dialogues, tertulias, mitotes, ateneos, and coyunturas construct a complex "grassroots think tank" while also generating the social infrastructure of community.

Increasingly, researchers such as Arjun Appadurai recognize how "social exclusion is ever more tied to epistemological exclusion." (Appadurai, 2000: 18) In opposition to dominant knowledge practices, Appadurai argues that the research imagination associated with Western discourses must embrace the knowledge production increasingly generated as part of "grassroots globalization." Appadurai proposes "researchers" engage a variety of knowledge producers fundamental to broader more complex grassroots globalization. ${ }^{39}$ Specifically, Appadurai's reformed Western research imaginary demands that taken for granted conventions of knowledge production allow for greater reflexivity and transparency. Such a challenge, according to Appadurai, invites Western academics to participate in a global knowledge production that promotes a dialogue between academics, public intellectuals, activists, and policy-makers. This new "new architecture" promises "a new pedagogy that closes the gap and helps to democratize the flow of knowledge about globalization itself.” Unfortunately, Appadurai does not fully account for the wide variety of community-based 
knowledge producers including those who do not associate with NGOs or publish in mainstream academic or public media outlets. (Appadurai, 2000: 18) Moreover, dialogues are not possible until there is a recognition of an "ecology of knowledges," or the epistemological diversity that parallels cultural diversity. According to de Soussa Santos, "both the proposals for radicalizing democracy -which points towards post-capitalist horizonsand the proposals for decolonizing knowledge and power -which points towards post-colonial horizons - will be feasible only if the dominant epistemology is subject to a critique allowing for the emergence of epistemological options that give credibility to the forms of knowledge that underlie those proposals.” (de Soussa Santos, 2007: xviiii-xxi) The ecology of knowledges framework not only argues that Western knowledge systems must expose how subaltern knowledge systems are marginalized, but also invites a different kind of engagement with the multiple, diverse "situated knowledges" that refuse to be erased by dominant epistemological structures of the West. ${ }^{40}$

It is important to note that all of the interconnected spaces comprise a social infrastructure that works as a de-compression chamber, an inbetween space that links "the community" with the non-profit and educational industrial complexes without being subsumed by bureaucratic exigencies or institutional agendas. TAZKP decolonizes and deterritorializes formal, dominant institutional spaces by gathering public intellectuals, scholar activists, community-based researchers, and local culture bearers for the purpose of pursuing local questions. The decompression chamber constructed by the community architecture of interconnected spaces is an experimental space that explores various efforts at deprofessionalization and cultural regeneration. Thus, TAZKP nurture a variety of oppositional knowledges through convivial processes that make it possible to share information, provide support, build networks, strategize for direct action, and coordinate resources between a wide variety of constituencies. More importantly, the TAZKP can work as incubators for practices beyond capital and the state - a fragile learning space that actively encourages the reconversion of nouns back into verbs. (Illich, 1990: 39) ${ }^{41}$

I have spent some time arguing for a more thorough theorization of a collective subject. I have relied in large part on Illich's "methodology" of convivial reconstruction as a guide. I have highlighted the importance of "learning" and collective research along with some of the epistemological dimensions of the current re-composition of struggle. Illich's notion of conviviality can assist in observing how learning is essential to the many “dislocated spaces" and "spontaneous" moments of struggle. My genealogy of conviviality not only interrogates the politics of a collective subject in the current conjuncture but insists that knowledge production is a critical element of a horizontal praxis and in the long run a collective subjectivity. As part of a larger project of democratic renewal, our extension of democracy should be, as Daniel Bensaïd reminds us, "scandalous right to the very end." ${ }^{42}$ 


\section{Notes}

${ }^{1}$ An earlier version of this paper was delivered at the Coloquio Internacional: Hacia La Construcción De Un NuevoParadigma Social Marzo 5-7, 2012 at the Unidad Xochimilco, de la Universidad Autónoma Metropolitana, en la Ciudad de México. My thanks to David Barkin and Gustavo Esteva as well as the other thoughtful participants for advancing my thinking.

${ }^{2}$ I am aware that the Autonomous Indigenous movement of the Global South is a diverse political formation composed of a variety of approaches and definitions of autonomy.

${ }^{3}$ Midnight Notes Collective offers an important caution about analyzing "crisis.” They distinguish between crisis as disequilibrium, "part of the normal dynamic of the ordinary run of things periodically meant to discipline the working class," and a real epochal crisis, the kind "that puts the 'social stability' and even the survival of the system into question." The task is to determine at what point a real epochal crisis actually becomes a "revolutionary rupture.” Midnight Notes, “Promissory Notes: From Crisis to Commons,” (2009): 2.

${ }^{4}$ For recent discussion of the Zapatistas' democratic project, see Reyes and Mara Kaufman, "Sovereignty, Indigeneity, Territory: Zapatista Autonomy and the New Practices of Decolonization,” South Atlantic Quarterly 110:2 (Spring 2011): 505-525.

${ }^{5}$ Probably one of the most well known of the occupations, Occupy Oakland has escalated from occupying and renaming Frank Ogawa plaza to Oscar Grant plaza, mobilizing a general strike, and initiating a long overdue social center. The mobilizations that animate the current Oakland Commune have been punctuated by pitched street battles between formations of multiple law enforcement agents notorious for police excess against a community with a long history of autonomous mobilization and resistance to state violence.

${ }^{6}$ For a discussion of the asamblea popular in Oaxaca in 2006, see Gustavo Esteva, "The Oaxaca Commune and Mexico’s Coming Insurrection,” Antipode 42:4 (2010).

${ }^{7}$ There have been a number of exclusions evident in the GA and formation of OSJ. One of the most notable "takeovers" has been through a brazen exercise of the privileges of patriarchy leading to the marginalization of youth, women, houseless folks, and the queer community. I am indebted to compañer@s in the 50.50 Collective, South Bay Unity Group, and Acción Zapatista South Bay for amplifying my understanding of the OSJ dynamics.

${ }^{8}$ Greater Mexico, according to Américo Paredes, "refers to all the areas inhabited by people of Mexican culture -not only within the present limits of the Republic of Mexico but in the United States as well-in a cultural rather than a political sense.” Américo Paredes, A TexasMexican Cancionero: Folksongs of the Lower Border (Austin: University of Texas Press, 1976): xiv.

${ }^{9}$ Addressing a paradox central to globalization, Sandro Messadra and Brett Neilson interrogate how the world that has been increasingly more open "to flows of capital and commodities" remains constricted when it comes to the movements of different human bodies. They argue for a revised conception of the international division of labor by taking up the category of the "multiplication of labor" which they insist escapes "the stable configurations such as the three worlds model or those elaborated around binaries such as center/periphery or North/south.” Messadra and Neilson conclude that the border, and 
especially the emergence of an internal border critical to capitalism's geographic scales is not designed to prevent migrant flow but to construct a differentiated laboring subject. "It tends itself to function," explain Messadra and Neilsen, "through a continuous multiplication of control devices that correspond to a multiplication of labor regimes and the subjectivities implied by them within each single space constructed as separate within models of the international division of labor. Corollary to this is the presence of particular kinds of labor regimes across different global and local spaces.” Thus, treating the border as method is an effort to reveal the "technologies of differential inclusion." Sandro Mezzadra and Brett Neilson, "Border as Method, or, the Multiplication of Labor," Transversal "Borders, Nations, Translations” accessed at <http://eipcp.net/transversal/0608/mezzadraneilson/en> accessed on March, 2009.

${ }^{10} \mathrm{I}$ am indebted to James Braggs at Project South for advancing my thinking in regards questions of abandonment as part of the violence of specific racial regimes.

${ }^{11}$ By "enemies of the state" I mean those criminalized subjects produced by intersecting projects through the media, state policy, and institutions of knowledge production.

${ }^{12}$ For an critical discussion of Du Bois and the psychological wage, see David Roediger, Wages of Whiteness: Race and the Making of the American Working Class (London: Verso, 2007).

${ }^{13} \mathrm{Du}$ Bois' theorization of the bargain between capital and labor is necessarily raced and therefore arguably more fundamental to capital as a social relation than the Autonomist Marxist privileging of the Keynesian bargain. We might also consider a number of lesser bargains such as the FHA, GI Bill, etc., as George Lipsitz has argued regarding America's "possessive investment in whiteness." It is useful to note the distinction between certain rights made possible through political citizenship against those privileges that accrue through cultural citizenship.

${ }^{14}$ I elaborate on the role of violence in organizing national belonging in "Mexican Border Troubles: Social War, Settler Colonialism, and the Production of Frontier Discourses, 18481880,” Ph. D. diss. University of Texas, Austin, 2003. For a discussion of imagined communities, see Benedict Anderson, Imagined Communities: Reflections on the Origin and Spread of Nationalism (London: Verso, 1991).

${ }^{15}$ See, for example, Aimé Césaire, Discourse on Colonialism (New York: Monthly Review Press, 2001).

${ }^{16}$ See Giorgio Agamben, State of Exception (Chicago: University of Chicago Press, 2005).

${ }^{17}$ The Zapatistas' discussion of the Fourth World War is particularly relevant here. See, for example, El Kilombo Intergalactico, Beyond Resistance: Everything, An Interview with Subcomandante Marcos (Durham: PaperBoat Press, 2007).

${ }^{18}$ Elsewhere I argue the U.S.-Mexico Border functions as a dispositif or apparatus that constructs the migrant as a criminal and disposable body.

${ }^{19}$ Henry Giroux argues persuasively that the "crisis” of the Katrina disaster revealed a domestic necropolitics, "a new kind of politics, one in which entire populations are now considered disposable, an unnecessary burden on state coffers, and consigned to fend for 
themselves.” Henry Giroux, "Reading Hurricane Katrina: Race, Class, \& Biopolitics of Disposability,” College Literature 33:3 (2006): 174.

${ }^{20}$ Of course, conviviality's most notable and distinguished advocates are Ivan Illich and Gustavo Esteva.

21 "As far as the distinction between the political and politics is concerned, Mouffe must be credited with giving a clear-cut definition: "by "the political," I mean the dimension of antagonism which I take to be constitutive of human societies, while by "politics" I mean the set of practices and institutions through which order is created, organizing human coexistence in the context of conflictuality provided by the political.” Sandro Mezzadra, "Beyond the State, beyond the Desert," South Atlantic Quarterly 110:4 (Fall 2001): 994.

${ }^{22}$ Elsewhere I argue that dignity as an analytical category, political practice, and strategic objective makes it possible to manage "difference.” See, Manuel Callahan, "Why Not Share a Dream,” Humboldt Journal of Social Relations 29:1 (2005): 6-38.

${ }^{23}$ Jaime Martínez Luna makes this point for comunalidad. See, for example, Martinez Luna, Jaime. “Comunalidad y Desarrollo,” CONACULTA, Dirección General de Culturas Populares e Indígenas. Centro de Apoyo al Movimiento Popular Oaxaqueño, (México 2003): 27-81.

${ }^{24}$ It is worth noting that in the current "crisis" corporate personhood has increasingly come under attack, a critique underscored by the widespread disapproval of the U.S. Supreme Court's recent ruling in the legal issues surrounding Citizens United.

${ }^{25}$ I am indebted to Gustavo Esteva to contributing significantly to my thinking regarding the dangers of abstraction on this and the earlier conceptualization of conviviality.

${ }^{26}$ Wendell Berry defines community as a deliberate effort to reclaim commons that is locally placed or rooted and defined both by arrangements and constraints. "Since there obviously can be no cultural relationship that is uniform between a nation and a continent, 'community' must mean a people locally placed and a people, moreover, not too numerous to have a common knowledge of themselves and their place.” Berry stresses that communities share situated knowledge of what works locally between generations to fulfill collectively determined obligations to one another. Wendell Berry, Sex, Economy, Freedom \& Community (New York: Pantheon Books, 1993): 120, 168.

${ }^{27}$ For more information about Universidad de la Tierra Califas see $<$ mitotedigital.org $>$. The Universidad de la Tierra Califas is also linked to Universidad de la Tierra Oaxaca <http:// unitierra.blogspot.com/>.

${ }^{28}$ According to Jaime Martínez Luna and others, the resistance that defines original peoples is one that has at times incorporated key elements of dominating forces reinventing and mitigating their most corrosive effects.

${ }^{29}$ The Center for Appropriate(d) Technologies promotes the generating and sharing of a wide variety of strategic, community-oriented technologies, or convivial tools. Given the commitment to autonomous strategies of community regeneration, "technology" is understood very broadly. Any technology necessarily results from collective invention that responds to shared struggle oriented to community regeneration. 
${ }^{30}$ The Language and Literacies Institute treats language very broadly, making sure not to privilege dominant forms of communication mostly associated with Western imperial languages. Convivial language and literacy projects provide critical opportunities to further the analysis of local issues through communication skills and a wide-variety of "reading" tools used to decode different literatures, shifting conjunctures, and emerging socio-political formations. Each tool is designed to assist in making autonomous praxis more legible.

31 The Theses Clinic supports compañer@s who are strategically producing formal research products, such as theses or dissertations, for official programs. The «clinic» provides a horizontal, collective space that encourages researchers to treat the afflictions of empiricism and positivism. Long-term participants as well as «drop-ins» at the «clinic» can access a variety of tools that can "inoculate" researchers and prevent the potential spread of elite claims to professionalized authority and practices that objectify communities of struggle. Various collaborations and collective research projects will help decontaminate more formal university projects by making available locally situated convivial community-based knowledge production "technologies."

32 The study-travel jornadas facilitate an extended, "networked” community through strategic exchanges of compañer@s whose local community involvement and intellectual itineraries benefit from travel and research between the Bay Area and other sites, including the Universidad de la Tierra "campuses” in Oaxaca, Puebla, and Chiapas.

${ }^{33}$ The Democracy Ateneo is an open space for reflection and action that interrogates the vexed and incomplete project of democratic promise. The learning space is animated by four critical themes: a) projects that attempt to democratize mainstream liberal institutions in the areas of learning, community wellness, food, and community safety; b) autonomous alternatives to traditional, representative democracy such as the Zapatista struggle and their critique of the party-state system, the analysis of the Fourth World War, and their experimentation with a politics of encounter, c) projects that have undermined democratic promise historically and politically including, for example, slavery, democratic despotism, development, neoliberalism, militarized policing, low intensity war, and (global) prison industrial complex; d) the strategies, practices, and diverse formations that promote the production of collective subjects.

${ }^{34}$ Following Hakim Bey, the one most associated with the term "temporary autonomous zone," I am hesitant to define the full concept suggested here agreeing with Bey that, "in the end the TAZ is almost self-explanatory." However, the TAZ, warns Bey, is not an exclusive end in itself, replacing all other forms of organization, tactics, and goals.” The TAZ is like an uprising which does not engage directly with the State, a guerrilla operation which liberates an area (of land, of time, of imagination) then dissolves itself to re-form elsewhere/ elsewhen, before the state can crush it. Because the State is concerned primarily with Simulation rather than substance, the TAZ can 'occupy' these areas clandestinely and carry on its festal purposes for a quite a while in relative peace.” According to Bey, "we recommend it because it can provide the quality of enhancement associated with the uprising without necessarily leading to violence and martyrdom. Hakim Bey, T.A.Z. The Temporary Autonomous Zone, Ontological Anarchy, Poetic Terrorism (New York: Autonomedia, 1991): 98-101.

${ }^{35}$ A tertulia refers to neighbors who gather at an accessible public space, such as a pub or coffee house, to share news and information that affect the community. Tertulias that achieve a more political focus, as we are suggesting here, can operate as Virtual Centers, meaning 
they can parallel the research efforts of more sophisticated elite «Research Centers» or «Think Tanks» without the costs or infrastructure. Thus, a consistent and accessible tertulia is a site of knowledge production where community members can develop projects, coordinate activities, facilitate networks, share resources, and promote research.

${ }^{36}$ Mitote is a signifier originally used by the Spanish during the "age of discovery" of the Americas to criminalize Indigenous resistance. Initially the term signified what were perceived to be sinister gatherings of debauchery and excess assumed to be the result of the free use of intoxicants. The celebration and declarations, to the Spanish, must have confirmed their worst fears of an Indigenous disposition to subversion and the constant worry of revolt. In this instance, the term has been re-appropriated as a category of analysis, strategic practice, and a political objective. In this sense the term refers to a "clandestine" gathering marked by ritualized celebration and sharing of knowledge between generations for community renewal. As strategic sites of insurgent learning, mitotes operate as spaces of encounter in service of complex, emergent strategies of rebellion and autonomous political formation.

${ }^{37}$ The deployment of an ateneo as a strategy of oppositional learning and research has a long history especially associated with the Spanish anarchist community of the late 19th century. The rise of the alterglobalization struggle, or "movement of movements," has witnessed a resurgence of "worker" organized research projects and learning spaces. Many of these new uses of the ateneo have drawn from the success of the horizontal autonomous practices associated with the social centers and the okupas active across Spain since the 1980s.

${ }^{38}$ Throughout we rely on coyuntura, or conjunctural analysis, as a foundation to co-generate strategic knowledges and develop plans of action. We approach coyuntura as a category of analysis, a space for epistemological rupture, and as a space to actively produce new knowledges. Inspired by the intersections of critical pedagogy and liberation theology in Latin America during the 70s and 80s, coyuntura links research, analysis, reflection, action, and community empowerment by encouraging participants to name, define, narrate and act on the struggle that impacts them in the current conjuncture, or what Gustavo Castro calls the "amplified present." Thus, coyuntura as a collective, horizontal practice of knowledge production exposes the competing strategies of opposing forces composed of key agents, projects, networks, and alliances. Not surprisingly, as an approach to analysis, coyuntura draws heavily on the major theoretical advances of various "marxisms" and "post-marxisms" to illuminate the intersections between structural and cultural forces operating in economic, political, social, and cultural contexts over time. Coyuntura can also refer to a gathering convened for the purpose of producing new knowledges by first generating an epistemological rupture -exposing the views, attitudes, values, and concepts that are taken for granted and prevent a group from arriving at an agreed plan of action. Making a collective's diverse, complex, and situated resources available often requires not only exposing the «common sense» but also revealing the sedimented technological expertise or those taken-for-granted concepts that can prevent a group from listening to one another, arriving at a shared analysis, and constructing new tools to solve local, immediate problems. For the most thorough treatment of coyuntura as a praxis, see Gustavo Castro Soto y Enrique Valencia Lomelí, Metodologia de Analisis de Coyuntura vols. 1-10 (México: Servicio Jesuita a RefugiadosMéxico y Servicio Informativos Procesados, A.C., 1995).

${ }^{39}$ For critiques of the popular attitudes and discourses underlying "globalization," see, for example, the discussion of "global thinking" in Gustavo Esteva and Madhu Prakash, Grassroots Post-Modernism: Remaking the Soil of Cultures (London: Zed Books, 1998). 
Polis, Revista de la Universidad Bolivariana, Volumen 11, $N^{\circ}$ 33, 2012

See also Leslie Sklar, “Social Movements and Global Capitalism,” in Fredric Jameson and Masao Miyoshi, eds., The Cultures of Globalization (Durham: Duke University Press, 1998).

${ }^{40}$ This theme has also been taken up by the coloniality of power group.

${ }^{41}$ See also, Raúl Sánchez Cedillo, "Towards New Political Creations: Movements, Institutions, New Militancy,” Translated by Maribel Casas-Cortés and Sebastian Cobarrubias. Accessed from <http://transform.eipcp.net/transversal/0707/sanchez/en> on August 24, 2009. Universidad Nómada, "Mental Prototypes And Monster Institutions: Some Notes by Way of an Introduction,” Translated by Nuria Rodríguez. Accessed from <http://transform.eipcp.net/ transversal/0508/universidadnomada/en> on August 2009.

${ }^{42}$ Daniel Bensaïd, “Permanent Scandal,” in Democracy in What State? (New York: Columbia University Press, 2011): 43. 


\section{Bibliography}

Agamben, Giorgio (2005), State of Exception.University of Chicago Press, Chicago.

Anderson, Benedict (1991), Imagined Communities: Reflections on the Origin and Spread of Nationalism. Verso, London.

Appadurai, Arjun (2000), «Grassroots Globalization and the Research Imagination,» Public Culture 12 (1): 1-19.

Bensaïd, Daniel (2011), “Permanent Scandal,” in Agamben, et. al., Democracy in What State? Columbia University Press, New York.

Berry, Wendell (1993), Sex, Economy, Freedom \& Community. Pantheon Books, New York.

Bey, Hakim (1991), T.A.Z. The Temporary Autonomous Zone, Ontological Anarchy, Poetic Terrorism. Autonomedia, New York.

Caffentzis, George (2012), "In the Desert of Cities: Notes on the Occupy Movement in the US," talk presented at "The Tragedy of the Market: From Crisis to Commons,” Vancouver, B.C./Coast Salish Territory.

Callahan, Manuel (2003), "Mexican Border Troubles: Social War, Settler Colonialism, and the Production of Frontier Discourses, 1848-1880,” Ph. D. diss. University of Texas, Austin.

Ídem (2005), "Why Not Share a Dream,” Humboldt Journal of Social Relations 29 (1): 6-38.

Castro Soto, Gustavo y Enrique Valencia Lomelí (1995), Metodologia de Analisis de Coyuntura vols. 1-10. México: Servicio Jesuita a RefugiadosMéxico y Servicio Informativos Procesados, A.C.

Ceceña, Ana Esther (2012), “On the Complex Relation Between Knowledges and Emancipations,” South Atlantic Quarterly 111 (1): 112132.

Césaire, Aimé. (2001), Discourse on Colonialism. Monthly Review Press, New York.

Cleaver, Harry (2001), Reading Capital Politically. AK Press, Oakland.

de Soussa Santos, Boaventura João; Arriscado Nunes; and Maria Paula Meneses (2007), Another Knowledge is Possible: Beyond Northern Epistemologies. Verso, London.

Deleuze, Gilles and Felix Guattari (2005), A Thousand Plateaus. University 
of Minnesota Press, Minneapolis.

Du Bois, W.E.B. (1915), “African Roots of War,” Atlantic Monthly 115 (5): 707-714.

El Kilombo Intergalactico (2007), Beyond Resistance: Everything, An Interview with Subcomandante Marcos. PaperBoat Press, Durham.

Esteva, Gustavo and Madhu Prakash (1998), Grassroots Post-Modernism: Remaking the Soil of Cultures. Zed Books, London.

Esteva, Gustavo (2009), “Another Perspective, Another Democracy,” Socialism and Democracy 23 (3): 45-60.

Ídem (2010), “The Oaxaca Commune and Mexico’s Coming Insurrection,” Antipode 42 (4): 978-993.

Federici, Sylvia (2000), “War, Globalization, and Reproduction,” Peace \& Change 25 (2): 153-165.

Ferrer, Jorge N. (2003), “Dialogic Inquiry as Spiritual Practice” Tikkun 18 (1): 29-32.

Foucault, Michel (1977), Language, Counter-Memory, Practice: Selected Essays and Interviews by Michel Foucault. Cornell University Press, Ithaca.

Gilmore, Ruth Wilson (2002), "Fatal Couplings of Power and Difference: Notes on Racism and Geography,” The Professional Geographer 54 (1): $15-24$.

Gilmore, Ruth Wilson (1998/99), “Globalization and US Prison Growth: from Military Keynesianism to post-Keynesianism militarism,” Race \& Class 40 (2-3): 171-188.

Giroux, Henry (2006) "Reading Hurricane Katrina: Race, Class, \& Biopolitics of Disposability,” College Literature 33 (3): 171-196.

González Casanova, Pablo (2005), “The Zapatista ‘Caracoles’: Networks of Resistance and Autonomy,” Socialism and Democracy 19 (3): 79-92.

González, Jorge. (2003), Cultura(s) y Ciber_cultur@..(s): Incursiones no lineales entre Complejidad y Comunicación, Universidad Iberoamericana Biblioteca Francisco Xavier Clavigero, México, D.F.

Holloway, John. (1998), “Dignity’s Revolt,” in John Holloway and Eloína Peláez, eds. Zapatista! Reinventing Revolution in Mexico, Pluto Press, London.

Illich, Ivan (1990), Tools for Conviviality. Marion Boyars, London. 
Martinez Luna, Jaime (2003), “Comunalidad y Desarrollo,” México: CONACULTA, Dirección General de Culturas Populares e Indígenas. Centro de Apoyo al Movimiento Popular Oaxaqueño. pp. 27-81.

Ídem (2012), “The Fourth Principle,” in Lois Meyer and Benjamín Maldonado Alvarado (eds.) New World of Indigenous Resistance. City Lights Books, San Francisco.

Mbembe, Achille (2003), “Necropolitics,” Public Culture 15 (1): 11-40.

Mezzadra, Sandro and Brett Neilson (2008) "Border as Method, or, the Multiplication of Labor," Transversal "Borders, Nations, Translations” accessed at <http://eipcp.net/transversal/0608/mezzadraneilson/en>.

Mezzadra, Sandro (2001), "Beyond the State, beyond the Desert,” South Atlantic Quarterly 110 (4): 989-997.

Midnight Notes (2009), "Promissory Notes: From Crisis to Commons.”

Paredes, Américo (1976), A Texas-Mexican Cancionero: Folksongs of the Lower Border. University of Texas Press, Austin.

Rancière, Jacques (2011), "Democracies against Democracy” in Agamben, et. al., Democracy in What State? New York: Columbia University Press.

Retort (2005), Afflicted Powers: Capital and Spectacle in a New Age of War. Verso, London.

Reyes, Alvaro and Mara Kaufman (2011) ,“Sovereignty, Indigeneity, Territory: Zapatista Autonomy and the New Practices of Decolonization,” South Atlantic Quarterly 110 (2): 505-525.

Roediger, David (2007), Wages of Whiteness: Race and the Making of the American Working Class. Verso, London.

Rodrigo Montero, Javier (2009), “Collective Pedagogies as Networked Activity: Possible Itineraries,” in Transductores: Pedagogías colectivas y políticas espaciales. Centro José Guerrero, Granada.

Rodriguez, Dylan (2012), "Beyond Police Brutality: Racist State Violence and the University of California,” American Quarterly 64 (2): 301-313.

Ross, Kristin (2011), “Democracy for Sale,” in Agamben, et. al., Democracy in What State? Columbia University Press, New York.

Sánchez Cedillo, Raúl (2007), “Towards New Political Creations: Movements, Institutions, New Militancy,” accessed from <http:// transform.eipcp.net/transversal/0707/sanchez/en>. 
Sklar, Leslie (1998), “Social Movements and Global Capitalism,” in Fredric Jameson and Masao Miyoshi (eds.) The Cultures of Globalization. Duke University Press, Durham.

Universidad Nómada (2008), "Mental Prototypes And Monster Institutions: Some Notes by Way of an Introduction,” accessed from <http:// transform.eipcp.net/transversal/0508/universidadnomada/en>.

Zibechi, Raúl (2010), Dispersing Power: Social Movements as Anti-State Forces. Oakland: AK Press.

Ídem (2012), Territories in Resistance: A Cartography of Latin American Social Movements. AK Press, Oakland.

Recibido: 15.10.2012

Aceptado: 07.11.2012 